\title{
Biological activities of extracts from Tongue fern (Pyrrosia lingua)
}

\author{
Sultanov Akhmadjon ${ }^{1}$ (D) - Shin Hyub Hong ${ }^{1}$ (D) $\cdot$ Eun-Ho Lee $^{1}$ (D) \\ Hye-Jin Park ${ }^{1}$ (D) Y Young-Je Cho' ${ }^{1}$ (D)
}

Received: 19 June 2020 / Accepted: 17 July 2020 / Published Online: 30 September 2020

(C) The Korean Society for Applied Biological Chemistry 2020

\begin{abstract}
In this study, Tongue fern (Pyrrosia lingua) plants that have been used traditionally as medicines. Their traditional medicinal uses, regions where indigenous people use the plants, parts of the plants used as medicines. This study was designed to assess the antioxidant and inhibition activities of extracts from $P$. lingua. In the $P$. lingua extracts was measured ethanol activity, $80.0 \%$ ethanol was high activity. The antioxidant activity was measured in 1,1-diphenyl-2-picrylhydrazyl (DPPH) and 2,2'-Azino-bis-(3ethylbenzothiazoline-6-sulfonic acid) (ABTS), assays. DPPH and ABTS radical in this experiment, solid and phenolic of extract were tested, but only an average concentration of $100 \mu \mathrm{g} / \mathrm{mL}$ was used. However, the phenolic extract is shown phenolic activity reached a peak. Also, phenolic extracts ware reached peak water and ethanol extracts. As a result, using the phenolic extracts did other antioxidant assays such as DPPH, ABTS, protection factor, and thiobarbituric acid reactive substances at $50-200 \mu \mathrm{g} / \mathrm{mL}$ concentrations. The activity of elastase and collagenase, inhibiting their activities may retard skin aging. $\alpha$-Glucosidase and $\alpha$-amylase, inhibitors need to be explored for the benefit of postprandial hyperglycemia in diabetic patients. Activities of tyrosinase, hyaluronidase and xanthine oxidase inhibitors of these enzymes are increasingly important ingredients in cosmetics and medications to protect the skin against hyperpigmentation and skin aging. Inhibition effects were investigated using the $P$. lingua extracts at $50-200 \mu \mathrm{g} / \mathrm{mL}$ concentrations. The expression levels of enzyme
\end{abstract}

Sultanov Akhmadjon and Shin Hyub Hong are contributed equally to this manuscript.

Young-Je Cho $(\triangle)$

E-mail:yjcho@knu.ac.kr

${ }^{1}$ School of Food Science \& Biotechnology, Kyungpook National University, Daegu 41566, Republic of Korea

This is an Open Access article distributed under the terms of the Creative Commons Attribution Non-Commercial License (http://creativecommons. org/licenses/by-nc/3.0/) which permits unrestricted non-commercial use, distribution, and reproduction in any medium, provided the original work is properly cited. inhibitions activities were decrease in dependent-concentrations manner when $P$. lingua extracts were treated.

Keywords Antioxidant - Beauty food - Enzyme inhibition . Tongue fern

\section{Introduction}

The whole fern, Pyrrosia lingua has been used as a drug in people medication such as in Japanese used dried condition in general medicine [1]. Moreover, P. lingua has been widely used in medicine like beneficial effect in pain, urinary stone formation and vaginal bleeding in Korea and Chine [2]. Besides, studies have confirmed that $P$. lingua possesses numerous biological properties, such as antibacterial, hyperglycaemic and antitumor activities [3]. P. lingua is a very common plant and has high bioactive elements, widely distributed on the sides in southwestern Chine and the indochina peninsula [4]. Some ferns have special or specialized leaves that have sporangia and sterile leaves that have no productive structure. However, on the physiology of the frond, various arguments can be made in favor of which sporangia will be poured [5].

Some tissues, organs, arteries, etc., including the dermal layer of the skin, are filled with extracellular matrix (ECM) proteins such as elastin, collagen, and hyaluronic acid. Have, in particular, the dermal layer of the skin maintains the elasticity of the skin and prevents wrinkles through cross-linking of elastin and collagen. However, when exposed to strong ultraviolet rays such as oxidative stress and ultraviolet-B, excessive production of reactive oxygen species or exposure to chemicals and microorganisms causes fibroblasts to age and fail to function properly. Due to this, the synthesis of ECM protein is lowered, and the signal transduction material for decomposing it and the enzyme secretion such as elastase and collagenase are promoted, resulting in wrinkles [6]. Also, skin melanocytes produce melanin by stimulation of 
UV and deliver it to keratinocytes, which are fundamentally mechanisms to protect the skin, but due to aging, the cycle of turn over, the regeneration period of the skin, is delayed and the melanin. When the accumulation amount increases, phenomena such as pigmentation and stain appear [7].

Furthermore, studies on whitening materials of natural materials that can suppress tyrosinase activity that regulates the initial rate of melanin production is continuing [8].

The purpose of this study was to evaluate the physiological activities of antioxidant, beauty foods and functional foods using the extracts of $P$. lingua. According to the above results, the content of total phenolic components and health functional food activities such as antioxidant and gout suppression, and cosmetic activities such as melanogenic improvement and pore reduction effect, etc., of water or water extract were confirmed, and it was judged that it could be used as a functional material.

\section{Materials and Methods}

\section{Samples and sample preparation}

The $P$. lingua has a small-sized epiphyte fern. Plant up to 10-30 $\mathrm{cm}$ tall. Plant leaf was dried (Jeiotech, Daegu, Korea) and ground with shredder machine (RT-08, Guohua ChME Inc. Tainan, Taiwan) to 40 mesh and incubated at room temperature until analysis used as a sample.

Extraction and analysis of total phenolic compounds and solid-phase extract of $\boldsymbol{P}$. lingua

The preparation process the $P$. lingua extracts for testing their applications has two different methods to use. Preparation of the extract measure physiological activity solid and phenolic content. In the two flasks add $P$. lingua extracts per $1 \mathrm{~g}$ of powder was added $200 \mathrm{~mL}$ distilled water (DW) both of flask and inside of flask solution and set to boil up to $100 \mathrm{~mL}$ and cooled. Also, ethanol activity was measured on $P$. lingua from 10 to $100.0 \%$ ethanol. In the result, ethanol extract was made two with $80.0 \%$ ethanol in $1 \mathrm{~g}$ of smelt powder add $100 \mathrm{~mL}$ both of this and in the shaking incubator at room temperature during the $24 \mathrm{~h}$. Each extract contains Whatman No. 1 filter paper (Whatman Inc, Piscataway, New Jersey, USA), optional rotary vacuum evaporator (Eyela NE, Tokyo, Japan) and first two solutions used as a phenolic sample. The second two solutions incubated in the freeze dryer FDS8518 (Ilshin Bio Base Co. Ltd, Dongducheon, Korea) at $-80{ }^{\circ} \mathrm{C}$ during the 4 days ready-made powder used as a solid sample. As well as both of the samples were diluted into the 4 concentration 50, 100, 150 , and $200 \mu \mathrm{g} / \mathrm{mL}$.

\section{Total phenolic contents}

Total phenolic content was determined by $1 \mathrm{~mL}$ of $95 \%$ ethanol and $1 \mathrm{~mL}$ of extract. First of all, add $5 \mathrm{~mL}$ of DW and add $0.5 \mathrm{~mL}$ of $0.5 \mathrm{~N}$ Folin-Ciocalteu reagent. Mix well using a vortex mixer
(KMC-1300V, Vision Scientific Inc., Daejeon, Korea) and leave for $5 \mathrm{~min}$, then add $1 \mathrm{~mL}$ of $\mathrm{Na}_{2} \mathrm{CO}_{3}$. Afterward, the absorbance Optizen 3,220 UV (Merasys Co. Ltd., Seoul, Korea) at $725 \mathrm{~nm}$ was measured within $1 \mathrm{~h}$ to obtain gallic acid. The amount was converted from the standard curve used [9].

\section{1,1-diphenyl-2-picrylhydrazyl (DPPH) radical scavenging activity} The DPPH scavenging activity was measured according to the method of Blois [10]. The initially, using $3 \mathrm{~mL}$ of $60 \mu \mathrm{M} \mathrm{DPPH}$ and was added to $1 \mathrm{~mL}$ samples as well as mixed by vortex mixer. So then all mixture was saved at room temperature during the 15 min and checked in the absorbance at $517 \mathrm{~nm}$ was measured for the DPPH radical scavenging effects. Also, our data on the comparative reaction of ascorbic acid, 2,6-di-tert-butyl-4-methylphenol (BHT) and propyl gallate indicates that the positive control [11].

\section{2,2'-Azino-bis-(3-ethylbenzothiazoline-6-sulfonic acid) (ABTS) radical cation decolourisation assay}

ABTS was measured according to the method of Fellegrini et al. [12]. Firstly, $5 \mathrm{~mL}$ of $7 \mathrm{mM}$ ABTS solution mixed with $88 \mu \mathrm{L}$ of $\mathrm{K}_{2} \mathrm{~S}_{2} \mathrm{O}_{8}$ (potassium persulfate) solution and incubated in the dark place such as refrigerator at $4{ }^{\circ} \mathrm{C}$ during the $12-16 \mathrm{~h}$. Secondly, adding the $88 \mathrm{~mL}$ ethanol in $1 \mathrm{~mL}$ of stock solution and mixed mixture as well as like positive control used BHT. Thirdly, in the absorbance at $734 \mathrm{~nm}$ of the dissolved solution controlled to $0.7 \pm 0.02 \mathrm{~nm}$ in the spectrophotometer. Moreover, in $50 \mu \mathrm{L}$ samples added $1 \mathrm{~mL}$ of ABTS solution, mixed with a vortex mixer for $30 \mathrm{~s}$. and from this time incubated at the room temperature during the $2.5 \mathrm{~min}$ as well as in the absorbance at $734 \mathrm{~nm}$ was measured for the activity of tongue fern by ABTS solution.

\section{Antioxidant protection factor (PF)}

The PF was measured according to the methods of Andarwulan and Shetty [13]. That is, $1 \mathrm{~mL}$ of a solution of $30 \mathrm{mg}$ of $\beta$ carotene dissolved in $50 \mathrm{~mL}$ of chloroform is placed in a water container for the evaporator, and chloroform is completely distilled in a $40{ }^{\circ} \mathrm{C}$ water bath, $20 \mu \mathrm{L}$ linoleic acid, $184 \mu \mathrm{L}$ Tween 40 and $50 \mathrm{~mL}$ of $0.1 \% \mathrm{H}_{2} \mathrm{O}_{2}$ was added to make an emulsion. The reaction sphere was mixed with $5 \mathrm{~mL}$ of emulsion in $100 \mu \mathrm{L}$ of a sample concentrations of mixed well, cooled by reacting at $50{ }^{\circ} \mathrm{C}$ for $30 \mathrm{~min}$ in a dark room, and absorbance was measured at $470 \mathrm{~nm}$. The PF value was calculated as the absorbance of the control versus the absorbance of the reaction.

\section{Thiobarbituric acid reactive substances (TBARs)}

TBARs were measured according to the methods of Buege and Aust [14]. Emulsions were used with 1\% linoleic acid and 1\% Tween 40 , and the reaction mixture was mixed with $0.8 \mathrm{~mL}$ of emulsion and $0.2 \mathrm{~mL}$ of samples with four concentrations and reacted in a $50{ }^{\circ} \mathrm{C}$ water bath for $12 \mathrm{~h}$. After the reaction, $4 \mathrm{~mL}$ of the TBA reagent was added to the reaction solution, soaked for 
$15 \mathrm{~min}$, cooled for $10 \mathrm{~min}$, and centrifuged at 2,000 rpm for 20 min. After centrifugation, the mixture was left for $10 \mathrm{~min}$, and then the supernatant was taken to measure absorbance at $532 \mathrm{~nm}$. The TBARs value was calculated and calculated as the difference in absorbance between the reaction and control groups of the sample solution.

\section{Elastase enzyme inhibition effect}

Elastase enzyme inhibitory effect using by the method of Kraunsoe et al. [15]. Prepared $0.8 \mathrm{mM}$ substrate of an assay for this in $1 \mathrm{~mL}$ of $0.2 \mathrm{M}$ Tris-HCl buffur ( $\mathrm{pH} \mathrm{8.0)}$ ) added $5 \mathrm{~g} \mathrm{~N}$-suc(Ala) ${ }^{3}$-p-nitroanilide and mixed well. Also, in a mixture of $0.1 \mathrm{~mL}$ of $\mathrm{N}$-succinyl-(Ala) $)^{3}$-p-nitroanilide solution $1.0 \mathrm{U} / \mathrm{mL}$ porcine pancreatic elastase (Sigma-Aldrich Co., St. Louis, MO, USA) $0.1 \mathrm{~mL}$ of enzyme solution and $50-200 \mu \mathrm{g} / \mathrm{mL}$ and added $0.1 \mathrm{~mL}$ of each sample of phenolic contents and then dissolve in $0.1 \mathrm{~mL}$ of DW was added instead of the sample. Finally, the reaction, the amount of $p$-nitroaniline produced was absorbed in $410 \mathrm{~nm}$. As the positive control for the experiment, epigallocatechin gallate (EGCG) was used. The inhibition rate (\%) was calculated as (1sample absorbance/absorbance of control $) \times 100$.

\section{Collagenase enzyme inhibition effect}

Collagenase enzyme inhibitory effect was measured according to the method of Wunsch and Heidrich [16], and 4-henylazobenzyloxycarbonyl-Pro-Leu-Gly-ProD-Arg $(0.3 \mathrm{mg} / 0.15 \mathrm{~mL})$ of $0.2 \mathrm{mg} / \mathrm{mL}$ collagenase (Sigma-Aldrich Co.) was added to a mixture of 0.25 $\mathrm{mL}$ of the dissolved substrate solution and $0.1 \mathrm{~mL}$ of each sample solution have concentrations of $50-200 \mu \mathrm{g} / \mathrm{mL}$ phenolic contents. After stopping the reaction by adding $0.5 \mathrm{~mL}$ of $6 \%$ citric acid, add $2 \mathrm{~mL}$ of ethyl acetate and then absorbance at $320 \mathrm{~nm}$ was measured. EGCG used as a positive control. The inhibitory effect of collagenase was found to decrease the absorbance of the reaction and control group of the sample solution.

\section{Hyaluronidase (HAase) enzyme inhibition effect}

According to Dorfman and Melvin method [17]. The test was conducted as follows; $0.1 \mathrm{M}$ acetate buffer ( $\mathrm{pH}$ 3.5) was mixed with 7,900 U/mL HAase (Wako Pure Chemical Industries, Osaka, Japan) dissolved. Also, add DW $0.05 \mathrm{~mL}$ and then $0.05 \mathrm{~mL} 0.3 \mathrm{M}$ sodium phosphate buffer, which is a $(\mathrm{pH}$ 5.3) and sample solutions were mixed and cultivated at $38{ }^{\circ} \mathrm{C}$ for $5 \mathrm{~min}$. Next, $0.4 \%$ of hyaluronic acid (substrate) was added and grown at $38{ }^{\circ} \mathrm{C}$ for $45 \mathrm{~min}$. The mixture for $3 \mathrm{~min}$ in a water bath for fully cooled. After adding $5 \mathrm{~mL}$ of albumin solution reagent, as a color-forming reagent, to the cooled reaction product. Finally, the inhibitory activity was calculated by using the data of absorbance taken at $585 \mathrm{~nm}$. Pyrrolidine dithiocarbamate used as a positive control, a known stronger inhibitory activity, and an nuclear factor- $\kappa \mathrm{B}$ (NF$\kappa \mathrm{B})$ inhibitor [18]. The following equation was used to make the calculation: Inhibition ratio $(\%)=(1$ absorbance of sample group/ absorbance of a control group) $\times 100$.

\section{Xanthine oxidase (XOase) enzyme inhibition effect}

XOase inhibition effect was measured according to the method Fitzgerald et al. [19]. That is, the reaction sphere is $2 \mathrm{mM}$ substrate solution dissolved in potassium phosphate buffer $(\mathrm{pH}$ 7.5) $0.1 \mathrm{~mL}$ of enzyme solution $(0.05 \mathrm{U} / 0.1 \mathrm{~mL})$ and $3 \mathrm{~mL}$ of xanthine $0.3 \mathrm{~mL}$ is added to the control, and $0.3 \mathrm{~mL}$ of $\mathrm{DW}$ is used instead of the sample. The reaction was added at $37{ }^{\circ} \mathrm{C}$ for $5 \mathrm{~min}$ and the finished reagent $20.0 \%$ trichloroacetic acid. After adding $1 \mathrm{~mL}$, centrifuge the reaction solution to remove protein. Induced uric acid was measured at absorbance $292 \mathrm{~nm}$. The $P$. lingua ethanol extract showed a better XOase inhibitory effect than allopurinol. Allopurinol was used for positive control. Inhibition rate $(\%)=(1-$ uric acid content of the sample/uric acid content of the control) $\times 100$.

\section{Tyrosinase enzyme inhibition effect}

Tyrosinase inhibition effect was measured according to the method of Hearing and Vincent [20]. The reaction port was $0.1 \mathrm{M}$ sodium phosphate buffer ( $\mathrm{pH}$ 6.8) $2.3 \mathrm{~mL}$ and $1.5 \mathrm{mM}$ substrate solution mushroom tyrosinase in $0.4 \mathrm{~mL}$ of L-tyrosine solution (Sigma-Aldrich Co., $250 \mathrm{U} / \mathrm{mL}$ ) $0.1 \mathrm{~mL}$ and $0.2 \mathrm{~mL}$ of sample to the control, add $0.2 \mathrm{~mL}$ of DW instead of the sample, the reaction was carried out at $37{ }^{\circ} \mathrm{C}$ for $20 \mathrm{~min}$. The reaction solution is absorbed in $475 \mathrm{~nm}$ and the positive control for the experiment was determined using kojic acid used. Inhibition rate (\%) of (1sample absorbance/control absorbance) $\times 100$.

\section{$\alpha$-Amylase enzyme inhibition effect}

Measurement of $\alpha$-amylase inhibitory activity is the agar diffusion method by Kim et al. [21], $\alpha$-amylase inhibition a starch agar plate was prepared by autoclaving $1 \mathrm{~L}$ solution containing $5 \mathrm{~g}$ agar and $5 \mathrm{~g}$ soluble starch for $15 \mathrm{~min}$ at $121^{\circ} \mathrm{C} .15 \mathrm{~mL}$ of the autoclaved solution was dispensed to a petri dish. Disc paper $(10 \mathrm{~mm}$ in diameter) was placed in the middle of the plate, and the solution containing $800 \mu \mathrm{L}$ sample and $200 \mu \mathrm{L} \alpha$-amylase $(1,000 \mathrm{U} / \mathrm{mL})$ was dispensed into the disc paper. After incubation at $37^{\circ} \mathrm{C}$ for 3 days, potassium iodide $\left(\mathrm{I}_{2}\right) /$ iodine $(\mathrm{KI})\left(5 \mathrm{mM} \mathrm{I}_{2}\right.$ in $\left.3 \% \mathrm{KI}\right)$ solution was added, followed by incubation for $15 \mathrm{~min}$ to measure the inhibition rate by calculating the width of the clear zone.

\section{$\alpha$-Glucosidase enzyme inhibition effect}

$\alpha$-Glucosidase inhibition was measured as previously reported [22]. The substrate was prepared by dissolving $1 \mathrm{mg}$ of p-nitrophenol$\alpha$-dglucopyranoside in $1 \mathrm{~mL} 50 \mathrm{mM}$ sodium succinate buffer $(\mathrm{pH}$ 6.8). To measure the inhibitory activity, $1 \mathrm{~mL}$ of the substrate was incubated for $30 \mathrm{~min}$ at $37^{\circ} \mathrm{C}$ with $0.1 \mathrm{~mL}$ of enzyme solution and $0.1 \mathrm{~mL}$ of $200 \mu \mathrm{g} / \mathrm{mL}$ of each sample. After the reaction, $3 \mathrm{~mL}$ of $5 \% \mathrm{Na}_{2} \mathrm{CO}_{3}$ was added, and the optical density was measured at $400 \mathrm{~nm}$. EGCG used as a positive control. An enzyme reaction with DW instead of samples was used as a control. 


\section{Statistical analysis}

Every test and experiment did more than five times. For checking statistical assay used IBM SPSS Statistics Client Documentation 25.0 for Windows (IBM SPSS Inc., Chicago, IL, USA) and used one-way ANOVA, followed by Duncan's multiple range tests. A $p$-value $<0.05$ was considered to indicate a statistically significant difference.

\section{Result and Discussion}

\section{Phenolic content of $P$. lingua}

In this experiment, high ethanol phenolic content in $P$. lingua extract. That it was the most active solution at $80 \%$ has a high activity $29.38 \mathrm{mg} / \mathrm{g}$ (Fig. 1) experiment. However, between 50 and $100.0 \%$ fluctuated the activity of ethanol. That $0 \%$ without ethanol is ridiculous $100.0 \%$ water with a sample powder, also a great activity. That $0 \%$ without ethanol is ridiculous $100.0 \%$ water with a sample powder, also a great activity. The content of watersoluble extract of pine needles reported by Yoo et al. [23].

\section{Biological activities from solid and phenolic extract from $P$. lingua}

Antioxidant and pro-oxidant in the body maintains homeostasis and balance. When this balance is broken and tilted toward oxidation promotion, it has a detrimental effect on cells, and this harmful action is oxidative. It is called oxidative stress. Oxidative stress causes diseases such as arteriosclerosis, heart disease, stroke, diabetes, cancer, and aging due to failure to repair damage to cells caused by free radicals or an increase in the amount of oxygen in the body and degradation of antioxidant substances [24]. Antioxidant activity in this experiment divided into two solid and phenolic of the extracts was tested DPPH and ABTS, but only in an average concentration of $100 \mu \mathrm{g} / \mathrm{mL}$ was used. After determination activities result, decisions for measuring other antioxidant activities. In this (Fig. 2A) is shown DPPH radical

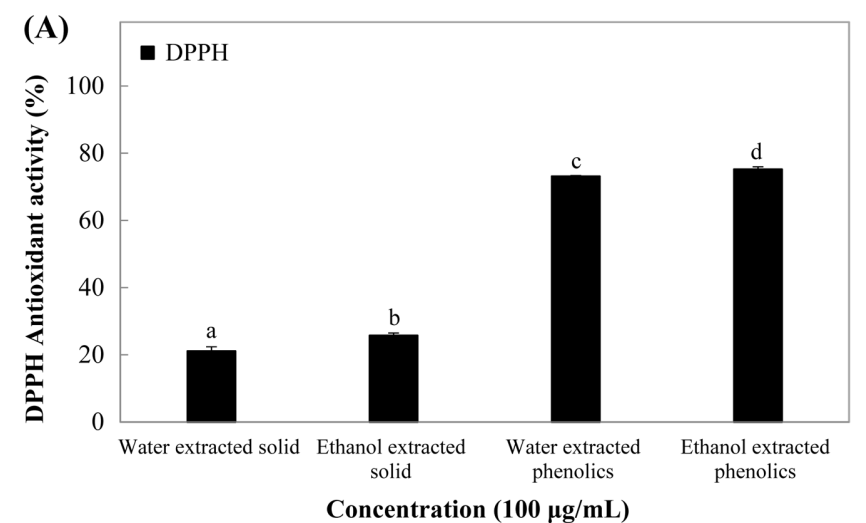

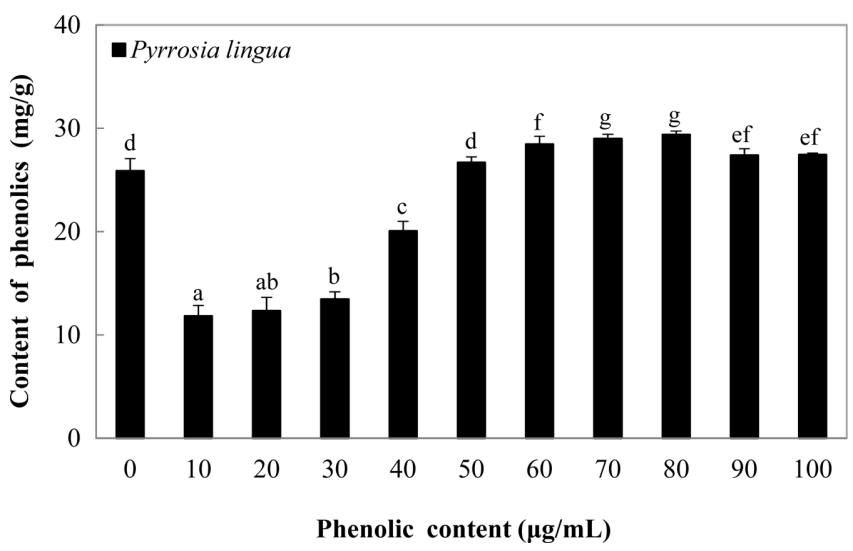

Fig. 1 The phenolic contents in extracts by various concentrations of ethanol from $P$. lingua. The result were expressed as means of triplicates \pm standard derivation with different superscript letters are significantly different at $p<0.05$ by Duncan's range test $(\mathrm{n}=3)$

activities phenolic extract reached a peak of 73.12 and $75.22 \%$, solid extract somewhat reaction both of the water and ethanol extracts 21.10 and $25.74 \%$. ABTS radical scavenging also tasted with phenolic extract (Fig. 2B) showed perfectly activity of phenolic water and ethanol extract both of it 98.86 and $94.48 \%$. However, in solid extract a sharp decrease from 34.85 to $35.99 \%$. As a result, phenolic extracts ware reached peak water and ethanol extracts.

\section{Antioxidant activities of phenolic extract from $P$. lingua.}

In the next step tested with four concentrations for antioxidant experiments with phenolic extracts. DPPH radical scavenging activity water extracts marked a rise (Fig. 3A) of 50, 100, 150, and $200 \mu \mathrm{g} / \mathrm{mL}$ concentrations from 31.98 to $48.13 \%$. Also, ethanol extracts partial growth between 49.36 and $61.44 \%$ in the same concentrations, as well as positive activities BHT significantly increases to $44.64-64.12 \%$ respectively. ABTS radical cation decolorization measured water extracts significant increase activities

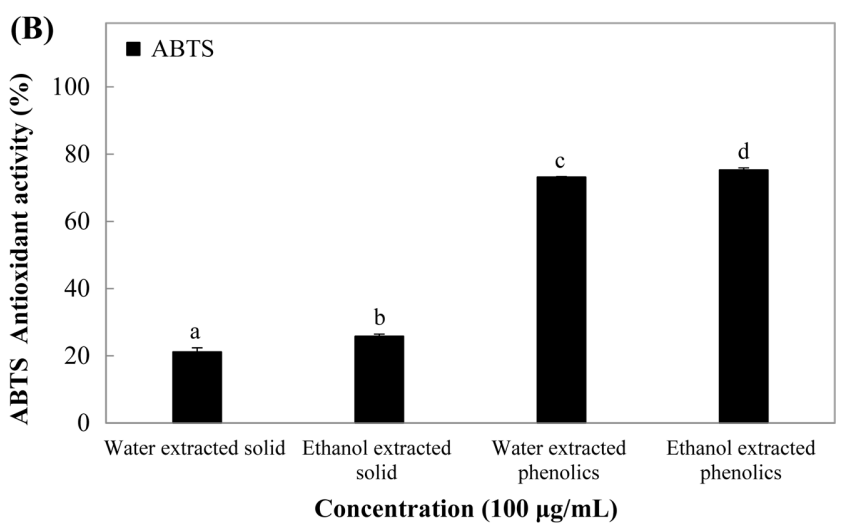

Fig. 2 The DPPH radical scavenging activity (A) and ABTS radical activity (B) on extracted solid and phenolics from $P$. lingua. The result were expressed as means of triplicates \pm standard derivation with different superscript letters are significantly different at $p<0.05$ by Duncan's range test $(n=3)$ 

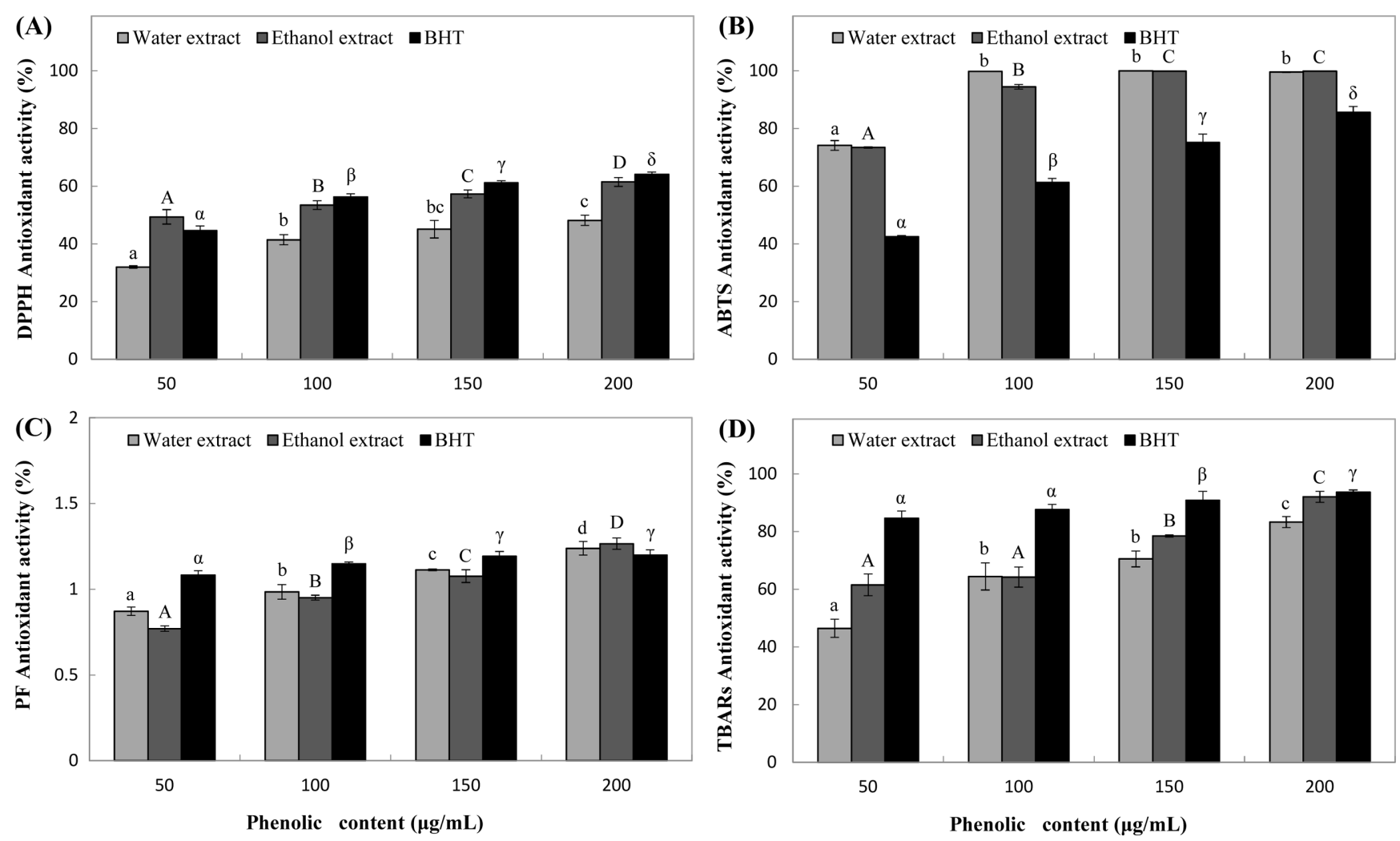

Fig. 3 The Antioxidant activities. DPPH (A), ABTS (B), PF (C) and TBARs (D) on extracted phenolics contents from P. lingua. The result were expressed as means of triplicates \pm standard derivation with different superscript letters are significantly different at $p<0.05$ by Duncan's range test $(n=3)$

(Fig. 3B) of $74.10 \%$ in $50 \mu \mathrm{g} / \mathrm{mL}$ and then a sharp increase of $99.79-99.53 \%$ from $100-200 \mu \mathrm{g} / \mathrm{mL}$ concentrations. In the ethanol extracts also dramatic growth to $73.42-99.90 \%$ in the past concentrations as well as the positive control BHT a marked rise of $42.44-85.65 \%$ antioxidant activity, from $50-200 \mu \mathrm{g} / \mathrm{mL}$ in phenolic contents. PF antioxidant activities in the water extracts were a sharp increase from 0.87 to $1.24 \%$ at $50-200 \mu \mathrm{g} / \mathrm{mL}$ concentrations and ethanol extracts also significant growth to $0.77-1.27 \%$ in the same as water extracts (Fig. 3C) phenolic contents. In the positive control rose from 1.08 to $1.20 \%$ in $50-200$ $\mu \mathrm{g} / \mathrm{mL}$ concentrations. TBARs antioxidant activities were positive control reached a peak in $50-200 \mu \mathrm{g} / \mathrm{mL}$ phenolic content at 84.58-93.69\%. Furthermore, water extracts a sharp increase (Fig. 3D) from 46.44 to $83.26 \%$. Besides, ethanol extracts a marked rise at $61.51-92.05 \%$ in $50-200 \mu \mathrm{g} / \mathrm{mL}$ concentrations.

\section{Elastase inhibitory activity of $\boldsymbol{P}$. lingua}

As a result of measuring the elastase inhibitory activity against. Extracts of water and ethanol were divided into four concentrations $50-200 \mu \mathrm{g} / \mathrm{mL}$. Inhibition activity in water extracts slightly rises to $11.08-23.18 \%$. Also, in ethanol extracts considerable increase inhibition activity in $21.87-60.20 \%$. In EGCG positive control elastase inhibition activity reached a peak from 93.07 to $95.01 \%$ in $50-200 \mu \mathrm{g} / \mathrm{mL}$ concentrations (Fig. 4A). The inhibitory effects of 150 medicinal plants on elastase activity were researched. Of these 150 plants, 70 did not inhibit porcine pancreatic elastase activity [25].

\section{Collagenase inhibitory activity of $\boldsymbol{P}$. lingua}

Estrogen reduction is one of the main causes of natural aging and photoaging, and the role of estrogen stimulates fibroblasts in the dermal layer to promote collagen synthesis and is involved in collagen metabolism to inhibit collagen decomposition, collagenase expression, thereby inhibiting collagen degradation. Suppress. As age increases, estrogen production stops due to natural aging, which promotes endocrine aging [25]. Collagenase inhibitory activity was measured by adding $P$. lingua extracts at concentrations of 50-200 $\mu \mathrm{g} / \mathrm{mL}$. As $P$. lingua water extract showed no inhibitory activities to $10.09-18.35 \%$. Besides, ethanol extracts activity reached a peak from 46.03 to $100.0 \%$ collagenase inhibitory effect (Fig. 4B). In EGCG positive control elastase inhibition activity a considerable increase from 93.07 to $95.01 \%$. Although it is lower than EGCG, which is used as an anti-wrinkle cosmetic material in the market, it showed high collagenase inhibitory activity.

\section{Hyaluronidase inhibitory activity of $\boldsymbol{P}$. lingua}

Hyaluronic acid is a macromolecular polysaccharide in which glucuronic acid and glucosamine are continuously combined [26]. 


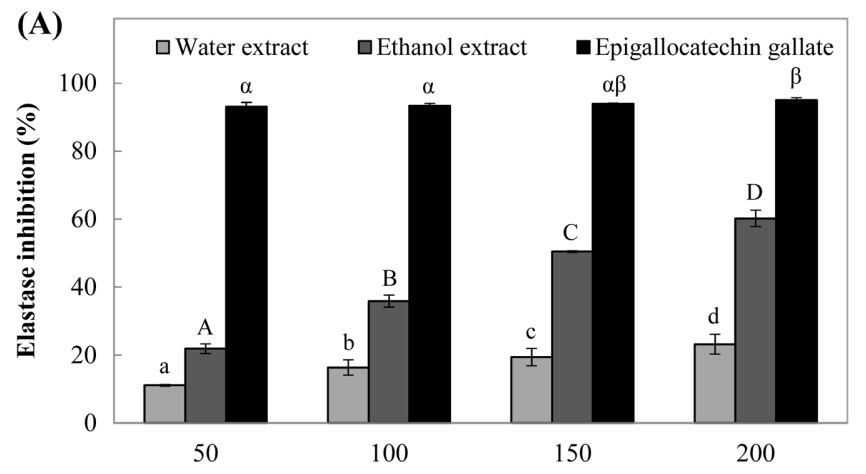

Phenolic content $(\mu \mathrm{g} / \mathrm{mL})$

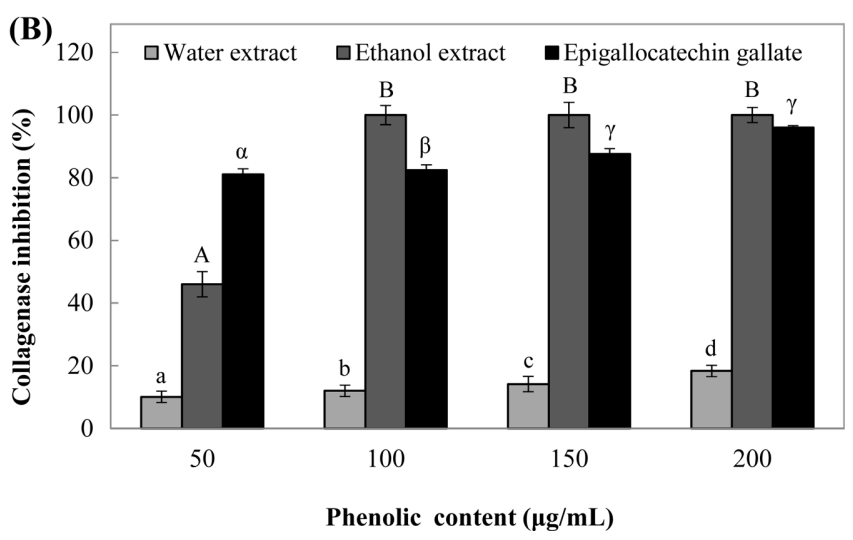

Phenolic content $(\mu \mathrm{g} / \mathrm{mL})$

Fig. 4 Inhibitory activity of $P$. lingua on elastase (A) and collagenase (B). The result were expressed as means of triplicates \pm standard derivation with different superscript letters are significantly different at $p<0.05$ by Duncan's range test $(\mathrm{n}=3)$
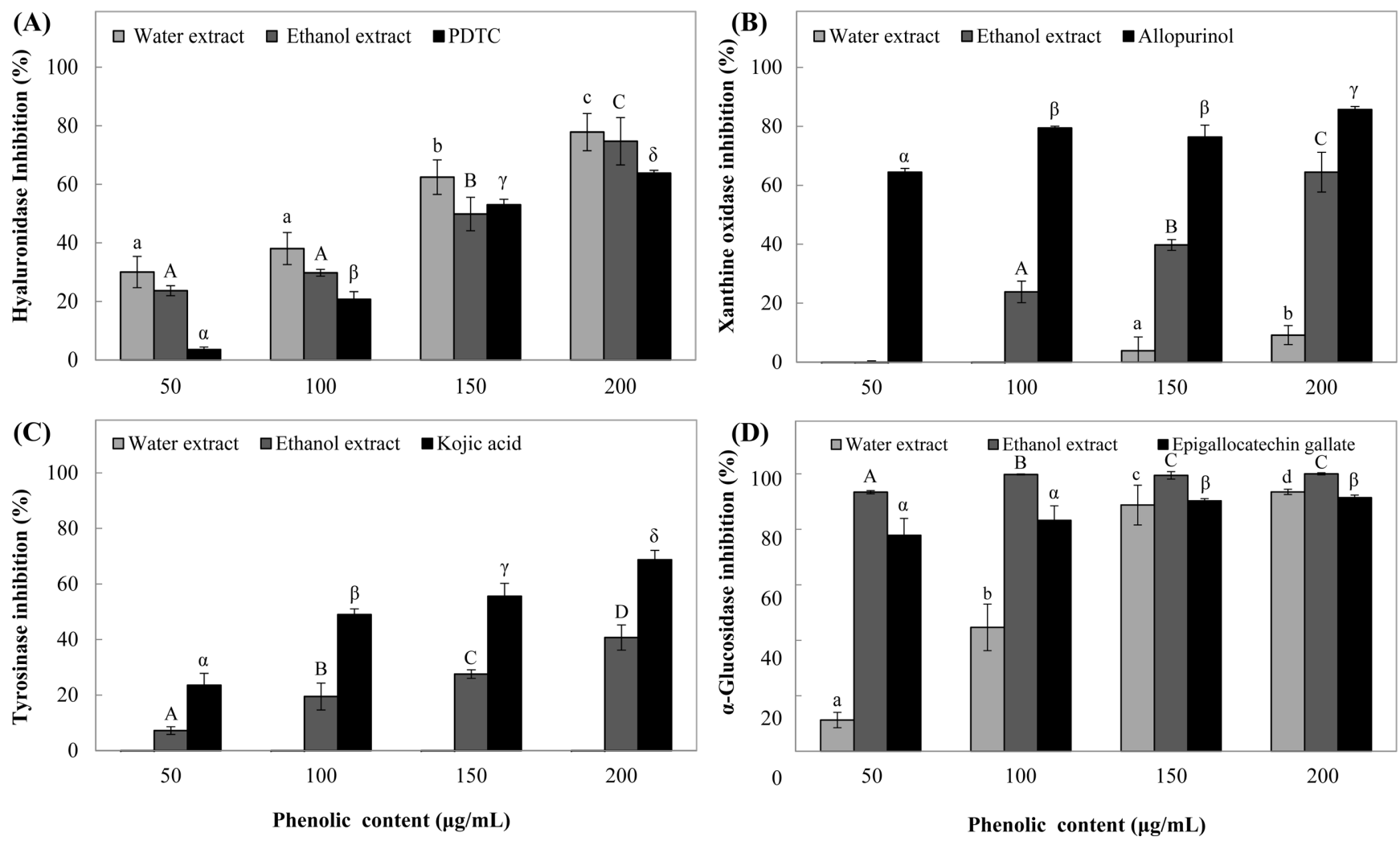

Fig. 5 Inhibitory activity of $P$. lingua on Hyaluronidase (A), Xanthine oxidase (B), Tyrosinase (C) and $\alpha$-Glucosidase (D). The results were expressed as means of triplicates \pm standard derivation with different superscript letters are significantly different at $p<0.05$ by Duncan's range test ( $\mathrm{n}=3$ )

Hyaluronic acid in polymer form inhibits inflammation by inhibiting phagocytic activity of macrophage. The small molecule forms inflammation in the process of wound healing [27]. Therefore, we investigated the anti-inflammatory effect of $P$. lingua extract by measuring hyaluronidase inhibitory activity. As a result of measuring hyaluronidase inhibitory activity of $P$. lingua extract, In the ethanol extracts at concentrations of $50-200 \mu \mathrm{g} / \mathrm{mL}$ were $23.65-74.70 \%$ hyaluronidase inhibition activity. The water extracts (Fig. 5A) showed a high inhibition rate was $77.82 \%$, in $200 \mu \mathrm{g} /$
$\mathrm{mL}$ concentration and all concentrations showed a statistically significant difference and increased in a concentration-dependent manner. As $P$. lingua has been widely used as a folk remedy for inflammatory reactions such as stomatitis, osteomyelitis, and hepatitis [28], the above experiments showed that the anti-inflammatory effect of $80.0 \%$ ethanol extract is very good. Also, the hyaluronic acid of the polymer increases the moisture content in the skin.

It is known to have a moisturizing effect to maintain [29]. Therefore, through the above experimental results, $P$. lingua 
extract has the inhibitory activity of hyaluronidase, thereby suggesting the possibility of application as a material of beauty foods having anti-inflammatory and moisturizing effect.

\section{Xanthin oxidase (XOase) inhibitory activity of $\boldsymbol{P}$. lingua}

Adenosine becomes IMP (inosine) by adenosine deaminase and IMP is hydrolyzed to hypoxanthine and D-ribose. This hypoxanthine is oxidized by XOase and passes through xanthine to become uric acid. GMP is also hydrolyzed to nucleoside guanosine and then cleaved to form free guanine, where the amino group is removed by hydrolysis to become xanthine and then to uric acid by XOase [30]. Excessive production of uric acid in the body, which accumulates in fractures, causes gout and kidney disease, which causes severe pain, and oxidative damage to biological tissues, leading to inflammation, arteriosclerosis, cancer it produces superoxide radicals that can cause a variety of diseases [31]. As a result of measuring the inhibitory effect of water extracts on XOase that produces uric acid and causes gout and oxidative damage, (Fig. 5B), water extract showed 3.88-9.19\% inhibitory effect at $150-200 \mu \mathrm{g} / \mathrm{mL}$ phenolic concentration and ethanol extract showed $23.84-64.46 \%$ inhibitory effect at $100-200 \mu \mathrm{g} / \mathrm{mL}$ phenolic concentration. It was assumed that the profiles of the phenolic components contained were different [32], and it was thought that studies related to this should be conducted in the future. Therefore, it was judged that the efficacy of improving gout and arthritis could be expected. In the water extract, XOase inhibitory effect was not observed.

\section{Tyrosinase inhibitory activity of $\boldsymbol{P}$. lingua}

Melanin, such as eumelanin and pheomelanin, which are produced to protect the skin from UV rays, affects the color of the skin [33]. Changes in skin collar are determined by several factors, including changes in melanin cell numbers, abnormal production and structure of melanosomes, and melanism in melanosomes [34]. This melanin blackens the skin as a substance finally produced through the oxidation of L-tyrosine-based enzyme tyrosinase [35]. Thus, measuring tyrosinase inhibitory activity can be seen in the whitening effect of $P$. lingua. In this experiment, we measured the tyrosinase inhibitory activity of $P$. lingua extract. As shown in (Fig. 5C), the ethanol extracts were a significant rise a $7.21-40.70 \%$ at concentrations of $50-200 \mu \mathrm{g} / \mathrm{mL}$. In the case of water, extracts had no tyrosinase inhibition effects. However, the kojic acid used as a positive control, inhibition rate was $68.72 \%$ in $200 \mu \mathrm{g} / \mathrm{mL}$ concentration range.

$\alpha$-Amylase and $\alpha$-glucosidase inhibitory activity of $P$. lingua $\alpha$-Glucosidase is a glycolytic enzyme present at the end of the small intestine in the body and is an in vivo essential enzyme involved in absorbing glucose by promoting the decomposition of $\alpha$-glucosidic bonds that release $\alpha$-glucose from carbohydrates. The $\alpha$-glucosidase inhibitor is used for the treatment of type 2 diabetes, but when used for a long time, some patients may

Table 1 Effect of inhibition on $\alpha$-amylase by water (A) and ethanol (B) extracts from P. lingua by disc method

(A)

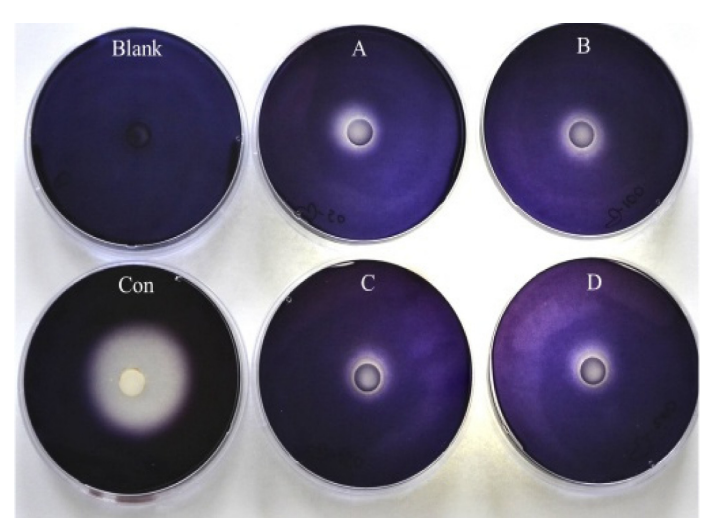

\begin{tabular}{cccc}
\hline \multirow{2}{*}{$\begin{array}{c}\text { Phenolic content } \\
(\mu \mathrm{g} / \mathrm{mL})\end{array}$} & \multicolumn{2}{c}{ Water extract } & \multicolumn{2}{c}{ Ethanol extract } \\
\cline { 2 - 4 } Control & Clear zone $\left(\mathrm{mm}^{2}\right)$ & Inhibition activity $(\%)$ & Clear zone $\left(\mathrm{mm}^{2}\right)$ \\
\hline 50 & $37.25 \pm 0.35$ & - & $35.75 \pm 1.77$ \\
100 & $22.50 \pm 0.71$ & $39.60 \pm 1.24^{\mathrm{a}}$ & $25.75 \pm 0.35$ \\
150 & $20.75 \pm 1.06$ & $44.30 \pm 2.26^{\mathrm{b}}$ & $23.50 \pm 0.71$ \\
200 & $18.75 \pm 0.35$ & $49.66 \pm 0.94^{\mathrm{b}}$ & $22.75 \pm 1.06$ \\
\hline
\end{tabular}

${ }^{1)} \alpha$-Amylase inhibition activity of water and ethanol extracts from $P$. lingua.

${ }^{2)}$ The result were expressed as means of triplicates \pm standard derivation with different superscript letters are significantly different at $p<0.05$ by Duncan's range test $(\mathrm{n}=3)$. A: $50 \mu \mathrm{g} / \mathrm{mL}$ of phenolic content, B: $100 \mu \mathrm{g} / \mathrm{mL}$ of phenolic content, C: $150 \mu \mathrm{g} / \mathrm{mL}$ of phenolic content, D: $200 \mu \mathrm{g} / \mathrm{mL}$ of phenolic content 
experience side effects such as bloating, vomiting, and diarrhea, which may limit its use [36]. Inhibitory effect of $\alpha$-amylase on $P$. lingua extracts (Table 1). In ethanol extract is inhibitory effects from $27.97-39.16 \%$. In the water extract, the inhibitory effect showed a high difference according to the concentration of the phenolic contends at between 39.60 to $53.69 \%$. The inhibitory effect of $\alpha$-glucosidase, the treatment must be treated at a concentration of $200 \mu \mathrm{g} / \mathrm{mL}$. $\alpha$-Glucosidase is an of the line extract $\alpha$-glucosidase inhibitory effect measured, (Fig. 5D). Furthermore, more highlight inhibitory activity ethanol extracts in Petri dishes around the paper disc $10 \mathrm{~mm}$ (Toyo Roshi Kaisha, Ltd., Tokyo, Japan). At concentrations of $200 \mu \mathrm{g} / \mathrm{mL}$ ethanol extracts, phenolic content has reached a pick $100.0 \%$ inhibitory effect. Consequently, the water extracts a slight variation from 11.25 to $93.50 \%$. As a passive control used EGCG, also showed high inhibitory effects from $77.87-91.42 \%$.

\section{References}

1. Yamashita H, Masuda K, Kobayashi T, Ageta H, Shiojima K (1998) Dammarane triterpenoids from rhizomes of Pyrrosia lingua. Phytochemistry 49: 2461-2466

2. Ju LH, Kwon J, Jeon H (2014) Pyrrosia lingua reduces nociception in mouse. Nat Prod Sci 20: 285-289

3. Cui L, Yingying Z, Wei Sh, Demin G (2016) Analysis of the HPLC fingerprint and QAMS from Pyrrosia spacies. Ind Crops and Prod 85: 29-37

4. Xin X, Liu Q, Zhang Y, Gao D (2016) Chemical composition and antibacterial activity of the essential oil from Pyrrosia tonkinensis (Giesenhagen) Ching. Nat Prod Res 30: 853-856

5. Chiou WL, Martin CE, Lin TCh, Hsu CC, Lin SH, Lin KC (2005) Ecophysiological differences between sterile and fertile fronds of the subtropical epiphytic fern Pyrrosia lingua (Polypodiaceae) in Taiwan. Am Fern J 95: 131-140

6. Tsuji N, Moriwaki Sh, Suzuki Y, Takema Y, Imokawa G (2001) The role of elastases secreted by fibroblasts in wrinkle formation: implication through selective inhibition of elastase activity. Photochem Photobiol 74: 283-290

7. Kim HS (2017) Effect of Ipomoea aquatica extract on antimelanogenesis and skin barrier function. Korean J Food Sci Technol 49: 519-523

8. Kim BA (2017) Inhibitory effects of fractions from Glycine soja Siebold et Zucc. on melanogenesis in B16F10 melanoma cells. J Soc Cosmet Sci Korea 43: 231-237

9. Folin O, Denis W (1912) On phosphotungstic-phosphomolybdic compounds as color reagents. Int J Biol Chem 12: 239-243

10. Blois MS (1958) Antioxidant determinations by the use of a stable free radical. Nature 181: 1199-1200

11. Sharma OP, Bhat TK (2009) DPPH antioxidant assay revisited. Food Chem 113: 1202-1205

12. Fellegrini N, Ke R, Yang M, Rice-Evans C (1999) Screening of dietary carotenoids and carotenoid-rich fruit extracts for antioxidant activities applying 2, 2-azinobis-(3-ethylenebenzothiazoline-6-sulfonic acid) radical cation decolorization assay. Meth in Enz 299: 379-389

13. Andarwulan N, Shatty K (1999) Phenolic content in differentiated tissue cultures of untransformed and Agrobacteriumtransformed root of anise (Pimpinella anisum L.). J Agric Food Chem 47: 1776-1780

14. Buege JA, Aust SD (1978) Microsomal lipid peroxidation. Mehods Enzymol 52: 302-310
15. Kraunsoe JA, Claridge TD, Lowe G (1996) Inhibition of human leukocyte and porcine pancreatic elastase by homologues of bovine pancreatic trypsin inhibitor. Biochemistry 35: 9090-9096

16. Wünsch E, Heidrich HG (1963) Zur quantitativen bestimmung der kollagenase. J Physiol Chem 333: 149-151

17. Dorfman A, Melvin LO (1948) A turbidimetric method for the assay of hyaluronidase. Int J Biol Chem 172: 367-375

18. Park T (2008) A study of isolation of biological activities phenolic compounds from Rubus coreanus fruit and application for stability of cubosome on advanced dosage formulation, Dissertation, Daegu Haany University

19. Fitzgerald KA, Rowe DC, Barnes BJ, Caffrey DR, Visintin A, Latz E, Monks B, Pitha PM, Golenbock DT (2003) LPS-TLR4 signaling to IRF$3 / 7$ and NF- $\kappa B$ involves the toll adapters TRAM and TRIF. The J Exper Med 198(7): 1043-1055

20. Hearing Jr, Vincent J (1987) Mammalian monophenol monooxygenase (tyrosinase): Purification, properties, and reactions catalyzed. Meth in Enz 142: 154-165

21. Kim JH, Lee SY, Park JM, Park JH, Kwon OJ, Lee JY (2014) Antioxidant activity and inhibition activity against $\alpha$-amylase and $\alpha$ glucosidase of Juniperus rigida Sieb extracts. Korean J Food Preserv 21: 396-403

22. Tibbot BK, Skadsen RW (1996) Molecular cloning and characterization of a gibberellin-inducible, putative $\alpha$-glucosidase gene from barley. Plant Mol Biol 30: 229-241

23. Yoo JH, Cha JY, Jeong YK, Chung KT, Cho YS (2004) Antioxidative effects of pine (Pinus denstifora) needle extracts. Korean Soc Life Sci 49: $1-4$

24. Ratnam DV, Ankola DD, Bhardwaj V, Sahana DK, Kumar MN (2006) Role of antioxidants in prophylaxis and therapy: A pharmaceutical perspective. J Control Release 113: 189-207

25. Lee KK, Kim JH, Cho JJ, Choi JD (1999) Inhibitory effects of 150 plant extracts on elastase activity, and their antiinflammatory effects. Inter J Cosmet Sci 21: 71-82

26. Meyer K (1947) The biological significance of hyaluronic acid and hyaluronidase. Physiol Rev 27: 335-359

27. Girish KS, Kemparaju K (2007) The magic glue hyaluronan and its eraser hyaluronidase: a biological overview. Life Sci 80: 1921-1943

28. English BP, Min W, Van OA, Lee KT, Luo G, Sun H, Cherayil BJ, Kou SC, Xie XS (2006) Ever-fluctuating single enzyme molecules: Michaelis-Menten equation revisited. Nat Chem Biol 2: 87-94

29. Kaatz GW, Gitlin SD, Schaberg DR, Wilson KH, Kauffman CA, Seo SM, Fekety R (1988) Acquisition of Clostridium difficile from the hospital environment. Am J Epidemiol 127: 1289-1294

30. Kim YH, Shin JW, Lee JS (2014) Production and anti-hyperglycemic effects of alpha-glucosidase inhibitor from yeast, Pichia burtonii Y257-7. Microbiol Biotechnol L 42: 219-224

31. Filha ZF, Vitolo IF, Fietto LG, Lombardi JA, Saúde-Guimarães DA (2006) Xanthine oxidase inhibitory activity of Lychnophora species from Brazil ("Arnica"). J Ethnopharmacol 107: 79-82

32. Lee EH, Park HJ, Kim NH, Hong EJ, Park MJ, Lee SH, Kim MU, An BJ, Cho YJ (2016) Biological activities of Aster scaber extracts. Korean J Food Preserv 23: 393-401

33. Wakamatsu K, Ito S (2002) Advanced chemical methods in melanin determination. Pigment Cell Res 15: 174-183

34. Ko JK, Bak JS, Jung MW, Lee HJ, Choi IG, Kim TH, Kim KH (2009) Ethanol production from rice straw using optimized aqueous-ammonia soaking pretreatment and simultaneous saccharification and fermentation processes. Bioresour Technol 100: 4374-4380

35. Pak TY, Ferreira S, Colson G (2016) Measuring and tracking obesity inequality in the United States: evidence from NHANES, 1971-2014. Popul Health Metr 14: 12-25

36. Puls W, Keup U, Krause HP, Thomas G, Hoffmeister F, Bayer AG (1977) Glucosidase inhibition. A new approach to the treatment of diabetes, obesity, and hyperlipoproteinaemia. J Nat Sci 64: 536-537 